\title{
Study of Post-Cold War Ideological Contests from the Coverage of Sochi Olympic Games
}

\author{
Xiaoyan LIU ${ }^{1,2, a}$ \\ ${ }^{1}$ Institute of Communication Studies, Communication University of China, Beijing, China \\ ${ }^{2}$ School of Languages and Communication Studies, Beijing Jiaotong University, Beijing, China \\ axyliu@bjtu.edu.cn
}

Keywords: ideology; nationalism, patriotism; hegemonism

Abstract. Western media try to politicize Sochi Olympic Games by pinpointing its problems on human rights and the freedom of press. This triggers an ideological tug between hegemonism and nationalism, which is manifested by Russia's nationalist news discourse in the coverage of world politics and patriotic news discourse in the coverage of domestic politics. Nationalism and patriotism are like two sides of a coin, working together to serve a nation by defending its sovereignty and national interests. As an enduring ideology, nationalism evolves to be the core power to change the trend of world politics after the Cold War, so the ideological contests continue to exist and de-politicization and de-ideologicalization of international sporting events remain to be a wishful thinking as ever.

\section{Introduction}

In Russia's preparations for the Winter Olympics, Western media gave excessive attention to Sochi by reporting such problems as violation of human rights, restriction of the press freedom, environmental damage and security concern. Besides those commonly-discussed problems, hot issues, like anti-homosexual law, corruption, delayed construction of Olympic venues and massive spending on Olympics, also drew Western criticism, making Sochi among "the most politically charged games in years." ${ }^{[1]}$ In the overblown public opinion, some of the Western countries boycotted Sochi Winter Olympics.

What happened to Sochi reminds us of what happened to 2008 Beijing Summer Games. The politicization of Olympic Games makes us worried: why is the sporting event politicized so often in the world? American media went so far as to measure 2014 Sochi Winter Games against 1980 Moscow Summer Games, arriving at the conclusion that both Games faced up to the same problems: human rights violation, dictatorship, public insecurity. This value-tainted judgment demonstrates ideological contests, which serves as the power to politicize Olympic Games.

\section{Ideology and News Discourse}

As a world event, Olympic Games naturally develop to be a stage for the major countries to contest on. The tug of national power is the tug of discourse power. Western media tend to build news discourse power on "freedom", "human rights" and "democracy", behind which there goes ideology. Michel Foucault thinks that discourse reconstructs and replicates ideology whereas ideology profoundly influences what to say and how to say. ${ }^{[2]}$ Communication, in essence, has to deal with issues of ideology, value and idea, therefore, everything is supposed to be interpreted in the "framework of ideology." ${ }^{[3]}$ In this sense, the objective nature of news is relative while the ideological nature of news is absolute. Currently, with the coordination of government, media industry and media practitioners, mass communication increasingly grows to be "a machine of ideology" which manufactures "agreeable information." ${ }^{,[4]}$

Then, what is ideology? The concept of ideology, which originated in France in 18 century, has undergone distortion, rewording and reconstruction for two centuries, but it still remains ambiguous at present. For example, the concept of ideology can be either descriptive or normative in that it can be used to describe an event (like political system) or to evaluate an event. ${ }^{[5]}$ Among so many definitions 
of ideology, the author of the paper quotes the one given by J. B. Tompson, a British sociologist. In his book Ideology and Modern Culture, Tompson defines ideology as "meanings that serve power.",[6] That means ideology is the way meanings which are constructed and transmitted by symbols serve to build and support a systematic and asymmetrical power relation (relation between the ruling and the ruled. ${ }^{[7]}$ Power basically determines what value meanings are going to have and meanings seek to legalize power and maintain its ruling position. In a word, ideology is the symbiosis and conspiracy of power and meanings.

Since meanings build and support an asymmetrical power relation, ideology has the nature of exclusiveness and hegemony which enables ideological contests to run through human history. Nowadays, globalization brings about the clash between civilizations and the contest between ideas worldwide. Mass communication becomes the forefront of ideological contests. Therefore, American media set anti-communism a mechanism which aims at not only the socialist countries but also those who oppose existing American systems. ${ }^{[8]}$ "Anti-communism" has already been internalized by American media and becomes their collective behavior. Kobland points out that the dominant news frame adopted by American media when reporting China is anti-communism and the coverage of communist countries "is unexceptionally focused on the problems and faults of Marxist government. ${ }^{,[9]}$ For example, when Western media covered 2008 Beijing Olympic Games, half of their news topics were about the problems in China. ${ }^{[10]}$ Besides, Western media frequently labeled China in ideological symbols as "communist China" or "communist country". In 2014 Sochi Olympics news coverage, Western media also focused on the problems, such as violation of human rights, restriction of the press freedom, environmental damage and security concern. This media hype "highlights that ideology still hangs over the earth and the Olympics are used as a stage for ideological demonstrations." $[11]$

\section{Ideologicalization of Sochi Winter Olympics}

Western media represent other countries in an either-or thinking pattern. In the Cold War it was either pro-communism or anti-communism. After the Cold War it changed to be either pro-America or anti-America. Under the leadership of Putin, Russia follows the independent and self-reliant diplomatic policy and does not yield to U.S. and other Western powers. In particular, Russia took Edward Snowden and offered political asylum to him, which made the relationship between Russia and U.S. go worse. Besides, the power struggle between Russia and the European Union on the issue of Ukraine further divided Moscow and the West. Major-country power confrontations surely result in the conflict of meanings that serve power, which, in reality, is revealed by ideologically disgracing Putin and Russia in American media.

In the coverage of Sochi Olympics, meanings were organized in an explicit way to echo ideology. For example, one news headline by the Associated Press(AP) on Jan. 27, 2014 said "Media watchdog blasts Sochi restrictions," which criticized Russian authorities for "cracking down on journalist, rights defenders, and civil activists in a way not seen since the break-up of the Soviet Union." ${ }^{[12]}$ Besides, in introducing the city of Sochi, the news referred to it as "Soviet-era summer resort." ${ }^{\text {"[13] }}$ Sochi Olympics were supposed to be a pure sporting event, but through many specific connections with the former Soviet Union, Western media politicized Sochi Olympics. Moreover, Western media were good at highlighting some meanings to construct ideology. Too much news coverage of security issue revealed the repressive political power of Russia. One news story by AP on Feb. 6 said, "the reasons (of terrorism) go back more than 150 years when Russian expanded into the Caucasus, land long ruled by the dozens of ethnic groups, many of them Muslims. After the fall of the Soviet Union, a guerrilla insurgency began fighting against Russian rule."[14] This cause-and-effect analysis of terrorism in Russia highlights Russian political repression. Putin's personal image was also smeared by ideological labeling. AP's Jan. 29 report went, "Putin has made the 2014 Winter Games his personal project from the very beginning." [15] "The Sochi Games have become a celebration of the 'cult of strength' for Russia's muscle-flexing leader, a demonstration of his and Russia's physical, intellectual and economic 
might." ${ }^{[16]}$ This report even drew a parallel between the state propaganda of 2014 Sochi Olympics and that of 1936 Berlin Olympics by saying, "the games took on a state propaganda aspect that ...has not been seen since the 1936 Summer Olympics in Berlin, which the Nazis used to promote their concept of racial supremacy." ${ }^{[17]}$ Meaning of this parallel is self-evident. Putin was even labeled as "dictator" and "thugocracy" by American media. The stereotypic coverage of Sochi and Putin by media has fueled an ideological contest between Russia and the West.

\section{Mediated Ideological Contests behind Sochi Olympics}

In the Cold War ideological contests were demonstrated by the confrontation between socialism/communism and capitalism while in the globalized world they are shown by the competition between nationalism and hegemonism. Sochi Olympics could be viewed as a political appeal made by Russia to display its rising national power and active role in the world affairs. The boycott of the Games by Western countries highlighted the contest between Russian nationalism and Western hegemonism, in which, Russia insisted on its nationalistic news discourse and defends its national sovereignty and national interests.

Putin did not care about Western leaders' boycott of Sochi Olympics. Instead, he believed Russia was one of the few countries in the world which had true national sovereignty, for Russia dared to pursue its national interests and say "no" to foreign interference. Recently, Putin endowed this subject with a strong ideological meaning. He portrayed Russia as the country which was courageous enough to fight against Western decadence and never yield. ${ }^{[18]}$ In response to Western media's attack on his ambition of holding the Olympics, Putin remarked frankly, "Hosting the Olympic Games is not to satisfy my political ambition, but to serve the national and people's interests. After the dissolve of the former Soviet Union and many years' turmoil in Caucasus, the overall situation in Russia makes people frustrated and pessimistic. Russia needs to shake off its spiritual burden and seeks to do something big to increase its communication with the rest of the world. ${ }^{,[19]}$ In doubts and suspicions, Russia declared the opening ceremony of the Olympic Games. The magnificent national narratives in the opening ceremony conveyed a simple but clear message to the world: Russia is back! This country does not have to bow in front of U.S. and European countries like what happened at the end of 1990s. Jonathan McEvoy, a journalist of British Daily Telegraph, hailed the opening ceremony by saying, "For Russia last night it marked its revival as a post-Soviet powerhouse, confident of its seat at the top table after two decades of doubt and despondency."[20]

Russian nationalism ideology takes the patriotic news discourse in domestic politics. In an interview, Putin said that organizing Sochi Olympics would "enhance and encourage national confidence and advance the national development. ${ }^{[21]}$ The spiritual significance of Sochi Olympics consisted in that "Russia is capable of pulling off large-scale projects in the humanistic field, including staging high-level sporting events to consolidate social basis and boost national morale, which will create conditions for the future development of Russia." ${ }^{[22]}$ Sochi Olympics stimulated the patriotism of Russians. According to the survey done by Russian Public Opinion Research Center, about two thirds of Russians showed their concern over the preparations for the forthcoming Olympics. ${ }^{[23]}$ Russians were united as one, taking Sochi Olympics as an important opportunity to realize Russia's "dream of strong nation." The Foundation of Russian Social Public Opinion released its survey on Jan. 30, 2014, indicating that 68\% of Russians believed that Russia could hold the Olympics successfully; 65\% thought that it was their strong wish to want this Olympics go smoothly; $26 \%$ deemed it an honor to have the Olympics held in Russia. "We want to let the world know we are the best;" $23 \%$ said that being a Russian, they felt proud of their country. "We are still patriots." ${ }^{[24]}$ Sochi Olympics were like a shot in the arm, which enhanced and encouraged Russian confidence and patriotism.

In the ideological contests behind Sochi Olympics we can trace the Cold War thoughts, but what more can be found is the U.S. hegemony. As Kiernan remarked, "Americans like to believe what they want is what the whole world wants." Acting as the world police, U.S. is imposing hegemony on every part of the world. U.S. hegemony is not confined to "the hegemony of U.S. dollars and weapons", 
instead, it is "the hegemony of the heart." David Rothkopf, the former senior official in U.S. Department of Commerce, addressed,

"It is the economic and political interests of the United States to ensure that if the world is moving toward a common language, it be English; that if the world is moving toward common telecommunication, safety, and quality standard, they be American; that if the world is becoming linked by television, radio, and music, the programming be American; and that if common values are being developed, they be values with which Americans are comfortable."[25]

Obviously, U.S. is ethnocentric and harbors a hegemonic ambition of pushing cultural imperialism worldwide.

U.S. implements cultural imperialism by promoting "universal values" in the world via its "soft power" of news outlets, meanwhile, it attacks and disgraces its rivals by innate ideological superiority. China, with its rising power in politics and economy, poses a threat to U.S. in terms of ideology and economy. That is why 2008 Beijing Olympics were politicized. Now, Putin's tough political stance and Russia's "dream of strong nation" embedded in Sochi Olympics has threatened U.S. hegemony. In fact, the very reason behind the boycott of Sochi Olympics by Western leaders was to curb the rise of Russia. Vladimir Evseev, a professor in the college of World Economy and World Relations in Moscow, said, "When Russia begins to be more active and independent on the world stage, the West will be annoyed. They choose to boycott Sochi Olympics to express their annoyance, for they don't want to see Russia implement a more active and independent foreign policy. If Russia acted as the West had instructed, such things wouldn't be happening, but Russia will not give up the pursuit of self-interests.",[26]

U.S. hegemony cannot prevent Putin's success. The opening ceremony of Sochi Olympics won widespread praises. Catchy words like "Russia back!" and "Confidently rising Russia" appear in news reports. An analyst remarked that Sochi Games ushered a new form of polarized world. It is not U.S. who has the say in the world affairs alone.

\section{Conclusions}

Kissinger, former U.S. Secretary of State, made comments on Putin, "First of all, he is a patriot. He felt ashamed of his country's experience in 1990s." This "shameful experience" compelled Putin not only to favor nationalism in his ruling thoughts, but also to uphold nationalism as a dominant political value, since "nationalism is the natural reaction given by the hurt people."[27]

Naoki Sakai points out that a nation stands against the West by its heterogeneity, but unifies itself by homogeneity. ${ }^{[28]}$ In fact, heterogeneity and homogeneity mean the same thing, that is nationalism, for "nationalism is a set of symbols, values and traditions which create self-identity for a community and also differentiate it from others. ${ }^{,[29]}$ In international politics, nationalism is represented by nationalist news discourse while in domestic politics it is represented by patriotic news discourse. Nationalism and patriotism are like two sides of a coin. They work together to move a nation forward and become a natural and powerful tool for a nation to defend its sovereignty and national interests. Therefore, as an enduring ideology, nationalism evolves to be the core power to change the trend of world politics after the Cold War. Ideological contests still keep going on and de-politicization and de-ideologicalization of world sporting events remain to be a wishful thinking as ever.

\section{References}

[1] Leonid Chizhov: Bach slams politicians over Sochi Olympics. Associated Press, Fe. 4, 2014.

[2] Changli Chen: Journal of Henan Normal Univerity Vol. 33 (2005), p.128.

[3] Denis McQuail: McQuail's Mass Cimmunication Theory (Trans Tsinghua University Press, China 2006), p.45.

[4] Zheng Yang: Journal of Xiangfan University Vol. 29 (2008), p.58.

[5] J. B. Tompson: Ideology and Modern Culture (Trans Yilin Press, China 2012), p.5. 
[6][7] J. B. Tompson: Ideology and Modern Culture (Trans Yilin Press, China 2012), p.7.

[8] Ruisheng Liu: Journalism and Communication Vol. 15 (2008), p.19.

[9] C. E Kobland, L. Du, and J. Kwan: Influence of Ideology in News and Reporting: Case study of New York Times' coverage of student demonstration in China and South Korea. Vol. 2 (1992), p. 66.

[10] Xiaoyan Liu, N.V. Leuven: Journalism and Communication Vol. 4 (2010), p.34.

[11] Jingwei Zhang: Sochi Olympics Become the Contests of Major Countries, Lianhe Zaobao, Jan. 24. 2014. http://www.chinanews.com/hb/2014/01-24/5777640.shtml.

[12][13] Pavel Golovkin: Media watchdog blasts Sochi restrictions, Associated Press, Jan. 27, 2014

[14] S. R. Hurst: Sochi Games hold echoes of 1980 Moscow Olympics. Associated Press, Feb. 6, 2014.

[15][16][17] Ivan Sekretarev: For Putin, Sochi Olympics carry big risks, rewards, Associated Press, Jan. 29, 2014.

[18][23] Olu Guan Cha: U.S. media: Russia after the Sochi Olympics. Reference News Net, Feb. 7, 2014. http://column.cankaoxiaoxi.com/2014/0207/343898.shtml.

[19] Yue Liu: Putin supervises the public security in Sochi Olympics. The International Herald Tribune. Feb. 7, 2014. http://ihl.cankaoxiaoxi.com/2014/0207/344024.shtml.

[20] Jonathan McEvoy: Winter Olympics ceremony "personal triumph" for Putin. Daily Telegraph. Feb. 8, 2014.

[21][22] Yan Zhao: Russian media: Putin claimed that Winter Olympics would display a new Russia. Xinhua Net, Jan. 19, 2014. http://news.xinhuanet.com/world/2014-01/19/c_119033891.htm.

[24] Jinfeng Jia: Russian public opinion survey says 68\% people believe Russia can host Olympics successfully. China News Net, Jan. 2014. http://www.chinanews.com/gj/2014/01-31/5801092.shtml.

[25] How does American culture win the world? News of the World, Nov. 13, 2003. http://sars.china.com.cn/chinese/CU-c/441526.htm.

[26] Xu Liu: Russian experts sing high praise for Xi Jinping's presence in Sochi Olympics: cordiality, friendliness and trustworthiness. People's Net-International Channel, Jan. 22, 2014. http://world.people.com.cn/n/2014/0122/c1002-24193545.html.

[27] Isaiah Berlin: Agaisnt the Current. (Trans. Yilin Press, China 2002), p.416.

[28] Zhichang Pan: Journal of Jiangsu Administration Institute Vol. 28 (2006), p. 29.

[29] Juan Nrofolk: Nationalism and Territory. (Trans Press of Minzu University of China, China 2009), p. 2. 